\title{
Is Deposit Insurance Necessary? A Historical Perspective
}

\author{
Charles W. Calomiris
}

The motivation and structure of various banking insurance experiments in U.S. history are analyzed, along with their political alternative, branch banks. In both the antebellum period and in the 1920s, insurance systems that relied on self-regulation, made credible by mutual liability, were successful, while compulsory state systems were not. Branch banking increased stability and resiliency to shocks.

F ollowing the current savings and loan collapse, recent studies of deposit insurance funds have focused on the perverse incentives created by deposit insurance when it is not fairly priced. Insurance encourages excess risk-taking by existing banks-particularly if prior losses leave them with little capital to lose from pursuing long shotsand allows unscrupulous, or simply inexperienced, entrepreneurs to enter banking as a means to finance their risky enterprises. The discipline of the market, which normally would prevent such intermediaries from having access to funds, is removed by insurance. Depositors of insured institutions have little incentive to discriminate with respect to where and with whom they place their funds.

Careful studies of the recent federal- and state-insured thrift experiences by Edward Kane, Paul Horvitz, and others, add credence to the view that insurance itself can be destabilizing. ${ }^{1}$ For example, bad initial realizations on investments were translated into a thrift and bank debacle in Texas because they were combined with high initial leverage and increased risk-taking by troubled institutions which responded to the initial adverse shocks by aggressively entering the speculative real estate loan market. Depositors presumably tolerated high leverage and increased risk-taking more than they would have had they not been insured. By promoting excessive leverage and increased risk-taking, deposit insurance made a bad situation much worse. The lack of political will by Congress and regulators to close insolvent institutions prolonged the "desperation" risk-taking and further magnified losses to the insurance funds.

The Journal of Economic History, Vol. L, No. 2 (June 1990). (C) The Economic History Association. All rights reserved. ISSN 0022-0507.

The author is Assistant Professor of Economics, Northwestern University, Evanston, IL 60208, and a member of the Research Department, Federal Reserve Bank of Chicago, 230 S. La Salle St., Chicago, IL 60604.

${ }^{1}$ See Edward J. Kane, "How Incentive-Incompatible Deposit-Insurance Funds Fail," mimeograph, Ohio State University, 1988; and Paul M. Horvitz, "The Causes of Texas Bank and Thrift Failures," mimeograph, University of Houston, 1989. 
Renewed discussion of the purpose and proper structure of deposit insurance has focused attention on the history of financial intermediaries and their regulation. U.S. financial history contains the answers to three fundamental questions of interest to would-be reformers. Why was bank liability insurance created in the first place? What evidence supports this presumed "special" need of banks? Which experiments with insurance were most successful, and which aspects of these experiments account for the accomplishment of legitimate goals?

The answer to the first question is similar across various historical instances-bank insurance was instituted to protect the economy's payments system from financial panics. ${ }^{2}$ Recent theoretical work on banking echoes this theme. Banks are especially vulnerable because they offer short-term (typically demandable) claims backed by longerterm assets whose value is not easily observable to depositors. ${ }^{3}$ Thus banks are vulnerable to panics induced by depositors' uncertainty about the value of their portfolios. Disturbances that increase the probability of insolvency of some class of bank borrowers-even if they are small relative to aggregate bank assets and concentrated in only a few banks-can provoke widespread disintermediation from all banks by depositors who lack information about the incidence or degree of the shock.

The social costs of such disturbances are high because banks provide a unique source of transacting balances and commercial credit to "information-intensive" borrowers. Disruptions of banking disrupt all industries' abilities to transact and operate effectively. Not surprisingly, it was this concern for the viability of the economy's payments system (the availability of liquidity and trade credit) that prompted insurance plans, starting with that of New York in 1829, and culminating in the federal system of the $1930 \mathrm{~s}^{4}$

Bank insurance was not exclusively the domain of the government historically. The information externality created by depositors' confusion about the precise incidence across banks of a given shock prompted private coinsurance among banks to reduce the potential for disintermediation and to coordinate the banking system's response to such crises when they did occur. Formal coinsurance arrangements among

\footnotetext{
${ }^{2}$ See Carter H. Golembe, "The Deposit Insurance Legislation of 1933: An Examination of its Antecedants and its Purposes," Political Science Quarterly (June 1960), pp. 189-95, and Eugene N. White, "The Political Economy of Bank Regulation," this Journal, 42 (Mar. 1982), pp. 33-42.

${ }^{3}$ The rationale behind this peculiar contracting structure is not at all obvious. For a critique of existing explanations and a new approach to this question, see Charles W. Calomiris and Charles M. Kahn, "The Role of Demandable Debt in Structuring Optimal Banking Arrangements," mimeograph, Northwestern University, 1989.

${ }^{4}$ The desire to insure wealth per se was not the primary motivation of bank insurance (see Golembe, "Deposit Insurance Legislation," pp. 189-95); rather, it was the desire to preserve liquidity. This explains why intermediaries other than banks (insurance companies, pension funds, and so forth) have not given rise to similar legislation.
} 
bank clearinghouse members, and less formal arrangements among other banks-especially in the branch-banking states of the antebellum South-provided many of the features of government deposit insurance. ${ }^{5}$ In these private insurance regimes banks agreed to make markets in each other's liabilities, to make interbank loans, and to coordinate suspensions and resumptions of convertibility to minimize disruptions during panics. In all cases, self-imposed regulations and mutual monitoring kept members of the privately established coalitions from "free riding" on the collective insurance.

It is important to note that unit banking laws (prohibitions of branch banking) increased the potential for such disturbances, and hampered banks' abilities to respond to them effectively. First, the confusion over the incidence of small shocks is accentuated in a system of many small banks, which makes runs more likely. Second, banks' abilities to coordinate behavior and coinsure depended on ease of communication and mutual monitoring (to prevent free riding), and these were hampered in systems of many, geographically isolated banks. Indeed, these barriers to private coinsurance explain why clearinghouse membership typically was limited to individual cities.

Historians long have stressed the destabilizing influence of unit banking and linked its peculiar prevalence in the United States to the unique vulnerability of U.S. banking historically. ${ }^{6}$ Indeed, studies of the political history of deposit insurance legislation show that it was the desire to preserve unit banking, and the political influence of unit bankers, that gave rise to the perceived need for deposit insurance, both in the antebellum period and in the twentieth century. ${ }^{7}$ It was understood early on (through observing the successful operation of branch banks in the South and in other countries) that branching-with its benefits both of greater diversification and coordination-provided an alternative stabilizer to liability insurance. But unit banks and their supporters successfully directed the movement for banking reform

\footnotetext{
${ }^{5}$ For discussions of clearinghouse coinsurance, see James G. Cannon, Clearing Houses, (Washington, DC, 1910), and Gary Gorton "Clearing Houses and the Origin of Central Banking in the United States," this Journal, 46 (June 1986). For a summary of similar operations in the branching antebellum South, see Thomas Govan, "The Banking and Credit System in Georgia" (Ph.D. dissertation, Vanderbilt University, 1936), and Charles W. Calomiris and Larry Schweikart, "The Panic of 1857: Origins and Regional Responses," mimeograph, 1989.

${ }^{6}$ See, for example, Oliver M. W. Sprague, History of Crises Under the National Banking System (Washington, DC, 1910); Gaines T. Cartinhour, Branch, Group, and Chain Banking (New York, 1931); John M. Chapman and Ray B. Westerfield, Branch Banking: Its Historical and Theoretical Position in America and Abroad (New York, 1942); Milton Friedman and Anna J. Schwartz, A Monetary History of the United States (Princeton, 1963); Eugene N. White, The Regulation and Reform of the American Banking System, 1900-1929 (Princeton, 1983); Charles W. Calomiris, R. Glenn Hubbard, and James T. Stock, "The Farm Debt Crisis and Public Policy," Brookings Papers on Economic Activity, 2 (1986); and Calomiris and Schweikart, "The Panic of 1857."

${ }^{7}$ Again, see Golembe, "Deposit Insurance Legislation."
} 
toward creating government insurance funds. All six antebellum states that enacted liability insurance were unit-banking states. In the antebellum branch-banking South neither government insurance, nor urban clearinghouses, developed. Similarly, the eight state insurance systems created from 1908 to 1917 were all in unit-banking states.

In evaluating the performance of the various government-created liability-insurance schemes below, I ask two principal questions: First, which experiments failed or succeeded, and why? Here I am particularly interested in ascertaining whether the failures of insurance systems were attributable to flaws inherent in their design, or to insurmountable exogenous shocks. And second, would allowing branch banking (the perceived alternative to insurance) have provided a more effective means to protect the payments system than bank insurance? ${ }^{8}$

\section{ANTEBELLUM SUCCESSES AND FAILURES}

New York's Safety Fund was established in 1829, funded by limited annual contributions of members and regulated by the state government. Losses severely depleted the accumulated resources of the fund from 1837 to 1841 until, in 1842 , it ceased to be able to repay losses of failed banks and thus ceased to provide protection to the payments system.

New York in 1838 created an alternative to the insured system through its free banking statute, and allowed Safety-Fund banks to switch to that system. The depletion in membership of the insured system kept its losses small during subsequent panics. After 1840 Safety-Fund banks comprised a small and continually shrinking proportion of total banks or total bank assets. Losses were also limited by the 1842 restriction on coverage of member banks' liabilities to bank notes, thus excluding the growing liability base in deposits.

Ultimately the small number of banks that chose to remain in the system and make continuing annual contributions to its fund did manage to repay in 1866 the obligations incurred some thirty years earlier, but this "success" was not anticipated in the intervening years (as shown by the high note discount rates attached to failed member-banks' notes during the 1850s), and the fund did not protect current bank liabilities or the payments system ex ante, as it was intended to do.

Not only did the system fail to provide protection to the payments system, it suffered unusually large losses due to fraud or unsound banking practices. While a supervisory authority was established to

\footnotetext{
${ }^{8}$ This article summarizes and extends the analysis presented in Charles W. Calomiris, "Deposit Insurance: Lessons from the Record," Economic Perspectives, Federal Reserve Bank of Chicago, 13 (May/June 1989), and "Do Vulnerable Economies Need Deposit Insurance? Lessons from the U.S. Agricultural Boom and Bust of the 1920s," in Philip Brock, ed., If Texas Were Chile: Financial Risk and Regulation in Commodity-Exporting Economies (Washington, DC, 1990).
} 
prevent fraud and excessive risk-taking, supervision was ineffectual, and fraud or unsafe practices were common. Ten of 16 member-bank failures prior to 1842 (the period when insurance was still perceived as effective) were traceable to fraud or unsafe practices. Moreover, such problems were not detected until after they had imposed large losses on the fund.

The failure of the Safety Fund was not the fault of external shocks, severe as they were. In aggregate, banking capital was large relative to losses, and thus coinsurance among all New York banks would have been feasible. Rather it was the design of the insurance system that made it weak. ${ }^{9}$ Upper bounds on annual premia prevented adequate ex ante insurance during panics, and ineffectual supervision allowed large risk-takers to free ride on other banks. Finally, adverse selection caused a retreat from the system through charter-switching to the alternative free-banking system once solvent banks realized the extent of losses.

Vermont and Michigan followed New York's example and suffered its problems. In Vermont, banks were even allowed to join and depart at will. It took only two bank failures-one due to fraud and the other because it joined the system after its prospects had deteriorated-to cause the dissolution of that system. Again, an incentive-compatible, broadly based system could have provided coinsurance among banks, but adverse selection and poor supervision prevented this.

Michigan's system, created in 1836, collapsed because it like the other two systems depended for its resources on accumulated contributions to the collective fund, which would be used to support banks during a crisis. The Michigan system had not time to accumulate a sufficient fund prior to the Panics of 1837 and 1839 and thus was unable to provide protection.

Not all antebellum experiments ended so disastrously. Indiana enacted a different sort of liability insurance plan in 1834, one based on the principles of self-regulation and unlimited mutual liability that would later be imitated by private clearinghouses. The Indiana system did not suffer the supervisory laxity or membership retreat of New York and Vermont, nor the illiquidity of Michigan and New York. Coverage was broad-based and there was no problem attracting and keeping members. During its 30-year history no insured bank failed. The system suspended convertibility in 1837 , and again in 1839 , but this was the last time banks were even forced to suspend. During the regional panic of 1854-1855 and the national Panic of 1857 all insured banks maintained operations and convertibility. During those same panics 69 of 126 nonmember, uncoordinated free banks failed in Indiana.

\footnotetext{
${ }^{9}$ For quantitative evidence on losses relative to bank capital for New York and other antebellum states, see Carter H. Golembe and Clark S. Warburton, Insurance of Bank Obligations in Six States During the Period 1829-1866 (monograph, Federal Deposit Insurance Corporation, 1958).
} 
The Indiana insurance system relied on bankers themselves to make and enforce laws and regulations through a Board of Directors and, importantly, gave the board authority to decide when to close a bank. Unlimited mutual liability provided bankers the incentive to regulate and enforce properly. The Indiana system was imitated in Ohio and Iowa, with similarly successful results. Ohio's law granted its Board of Control even greater authority than Indiana's board, allowing it virtually unlimited discretionary powers during a banking crisis, including the right to force banks to make loans to one another. Interbank loans were successfully used during the Panic of 1857 to avoid suspension of convertibility. The insured banks, it seems, even came to the assistance of nonmember banks during the Panic, as indicated by flows of interbank loans. Only one Ohio bank failed during the crisis, and it was not a member of the insured system. Iowa's system was in place for a shorter and more stable period, but its operation was similarly successful.

Like clearinghouses, these three successful insurance schemes aligned the incentive and authority to regulate and made insurance protection credible through unlimited mutual liability among banks. Like Southern branch banks in the Panics of 1837 and 1857, these systems were able to minimize systemic disruption through a coordinated, incentive-compatible response. They were brought to an end not by insolvency, but by federal taxation of bank notes designed to promote the National Banking System.

\section{THE SECOND, POSTBELLUM WAVE OF STATE INSURANCE}

The eight deposit-insurance fund systems of the early twentieth century failed to learn the lessons of the antebellum experience; they repeated and compounded the earlier errors of New York, Vermont, and Michigan. Supervisory authority was placed in government, not member-bank, hands, and often its use or disuse was politically motivated. ${ }^{10}$ Furthermore, the numbers of banks insured were many more than in the antebellum systems (often several hundred), and this further reduced a bank's incentive to monitor and report the misbehavior of its neighbor banks, since the payoff from detection was shared with so many, and the cost of monitoring was private.

During the halcyon days for agriculture, from 1914 to 1920, deposit insurance prompted unusually high growth, particularly of small rural banks on thin capital. The insured states' banks grew faster, were smaller, and had lower capital ratios than their state-chartered counterparts in fast-growing, or neighboring states. Tables 1,2 , and 3 compare the growth, average size, and capitalization of insured state-chartered banking systems, first by comparing the highest-growth insured and

\footnotetext{
${ }^{10}$ For examples, see Thomas B. Robb, The Guaranty of Bank Deposits (New York, 1921).
} 
TABLE 1

HIGH-GROWTH STATES: INSURED VERSUS UNINSURED

\begin{tabular}{|c|c|c|c|c|c|c|}
\hline & \multicolumn{2}{|c|}{$\begin{array}{c}\text { Proportion of Assets } \\
\text { in } 1914 \text { to Assets in } \\
1920\end{array}$} & \multicolumn{2}{|c|}{$\begin{array}{c}\text { Assets per Bank, } 1920 \\
\text { (\$ thousands) }\end{array}$} & \multicolumn{2}{|c|}{$\begin{array}{l}\text { Ratio of Capital to } \\
\text { Total Assets, } 1920\end{array}$} \\
\hline & $\begin{array}{c}\text { National } \\
\text { Bank }\end{array}$ & $\begin{array}{l}\text { State } \\
\text { Bank }\end{array}$ & $\begin{array}{l}\text { National } \\
\text { Bank }\end{array}$ & $\begin{array}{l}\text { State } \\
\text { Bank }\end{array}$ & $\begin{array}{l}\text { National } \\
\text { Bank }\end{array}$ & $\begin{array}{l}\text { State } \\
\text { Bank }\end{array}$ \\
\hline \multicolumn{7}{|l|}{ Uninsured } \\
\hline Arkansas & 0.408 & 0.379 & $\$ 1,020$ & $\$ 456$ & 0.084 & 0.085 \\
\hline Colorado & 0.522 & 0.450 & 1,069 & 460 & 0.081 & 0.083 \\
\hline Idaho & 0.341 & 0.316 & 1,088 & 487 & 0.059 & 0.088 \\
\hline Iowa & 0.507 & 0.503 & 1,301 & 562 & 0.057 & 0.104 \\
\hline Minnesota & 0.509 & 0.406 & 1,979 & 425 & 0.054 & 0.069 \\
\hline Missouri & 0.490 & 0.540 & 5,507 & 572 & 0.063 & 0.072 \\
\hline Montana & 0.495 & 0.489 & 761 & 436 & 0.077 & 0.091 \\
\hline New Mexico & 0.501 & 0.352 & 963 & 347 & 0.073 & 0.119 \\
\hline Wyoming & 0.314 & 0.315 & 1,365 & 300 & 0.048 & 0.090 \\
\hline Average & 0.454 & 0.418 & 1,673 & 448 & 0.066 & 0.090 \\
\hline \multicolumn{7}{|l|}{ Insured } \\
\hline Kansas & 0.463 & 0.380 & 977 & 326 & 0.066 & 0.079 \\
\hline Mississippi & 0.506 & 0.335 & 1,843 & 664 & 0.069 & 0.066 \\
\hline Nebraska & 0.537 & 0.335 & 1,566 & 335 & 0.057 & 0.082 \\
\hline North Dakota & 0.485 & 0.367 & 563 & 248 & 0.068 & 0.081 \\
\hline Oklahoma & 0.309 & 0.259 & 1,096 & 346 & 0.126 & 0.070 \\
\hline South Dakota & 0.400 & 0.351 & 862 & 376 & 0.053 & 0.062 \\
\hline Texas & 0.414 & 0.391 & 1,588 & 375 & 0.071 & 0.112 \\
\hline Average & 0.447 & 0.344 & 1,231 & 389 & 0.073 & 0.078 \\
\hline
\end{tabular}

Source: Board of Governors of the Federal Reserve System, All Bank Statistics (Washington, DC, 1959).

uninsured systems, and then by comparing insured-banking systems with neighboring uninsured state-chartered systems and uninsured national-chartered banking in each of the states. Table 3 reports regression results that confirm the unusually high growth of statechartered insured banks (controlling for other variables) relative to other agricultural states. A decomposition among voluntary and compulsory state insurance systems reveals that the incentives to grow were especially pronounced in the compulsory insurance systems (where the potential for cross-subsidization, or free riding through excessive risktaking, was highest).

When agricultural prices fell, insured banking systems suffered higher rates of decline and failure than uninsured state-chartered banks in agricultural states and showed an even greater difference in the asset shortfalls (relative to deposits) of insolvent banks. All the insurance fund systems collapsed during the 1920 s. $^{11}$ Insured systems also saw

\footnotetext{
${ }^{11}$ For summaries of the specific historical experiences, see American Bankers Association, The Guaranty of Bank Deposits (New York, 1933), and Federal Deposit Insurance Corporation, Annual Report (Washington, DC, 1956).
} 
TABLE 2

STATE-CHARTERED REGIONAL COMPARISON: INSURED VERSUS UNINSURED

\begin{tabular}{|c|c|c|c|}
\hline & $\begin{array}{c}\text { Ratio of Assets in } \\
1914 \text { to Assets in } \\
1920\end{array}$ & $\begin{array}{l}\text { Assets per Bank, } 1920 \\
\text { ( } \$ \text { thousands) }\end{array}$ & $\begin{array}{l}\text { Ratio of Capital to } \\
\text { Total Assets, } 1920\end{array}$ \\
\hline \multicolumn{4}{|l|}{ Uninsured } \\
\hline Arkansas & 0.379 & $\$ 456$ & 0.085 \\
\hline Colorado & 0.450 & 460 & 0.083 \\
\hline Iowa & 0.503 & 562 & 0.067 \\
\hline Idaho & 0.316 & 487 & 0.077 \\
\hline Minnesota & 0.406 & 425 & 0.069 \\
\hline Missouri & 0.540 & 572 & 0.072 \\
\hline Montana & 0.489 & 436 & 0.091 \\
\hline New Mexico & 0.352 & 347 & 0.119 \\
\hline Wyoming & 0.315 & 300 & 0.090 \\
\hline Average & 0.418 & 448 & 0.084 \\
\hline \multicolumn{4}{|l|}{ Insured } \\
\hline Kansas & 0.380 & 326 & 0.079 \\
\hline North Dakota & 0.367 & 248 & 0.081 \\
\hline Nebraska & 0.335 & 335 & 0.082 \\
\hline Oklahoma & 0.259 & 346 & 0.070 \\
\hline South Dakota & 0.351 & 376 & 0.062 \\
\hline Texas & 0.391 & 375 & 0.112 \\
\hline Average & 0.347 & 334 & 0.081 \\
\hline \multicolumn{4}{|l|}{ Uninsured } \\
\hline Alabama & 0.553 & 543 & 0.087 \\
\hline Georgia & 0.412 & 534 & 0.097 \\
\hline South Carolina & 0.390 & 536 & 0.085 \\
\hline Average & 0.452 & 538 & 0.090 \\
\hline \multicolumn{4}{|l|}{ Insured } \\
\hline Mississippi & 0.335 & 664 & 0.066 \\
\hline
\end{tabular}

Source: Board of Governors of the Federal Reserve System, All Bank Statistics (Washington, DC, 1959).

greater delays in closing and liquidating insolvent banks, reminiscent of politically motivated delays during the current thrift crisis. ${ }^{12}$

The three states that had long-lived, free-entry, compulsory deposit insurance (which provided the worst and most prolonged incentives for risk-taking) experienced the most drastic losses by far among the stateand national-chartered systems. While several state-chartered systems experienced comparable shocks to these three (North Dakota, South Dakota, and Nebraska), in no other cases were the asset shortfalls of insolvent banks nearly large enough to threaten the capital of the banking system as a whole (see Table 4). In contrast, these three states showed shortfalls of between 1.5 and 5 times remaining bank equity of state banks.

12 Detailed evidence on each of these points is provided in Calomiris, "U.S. Agricultural Boom and Bust." 
TABLE 3

REGRESSION RESULTS: EARLY ASSET GROWTH OF STATE-CHARTERED BANKS ${ }^{\mathrm{a}}$

a. Dependent variable: Growth in total assets of state-chartered banks, 1914-1920

\begin{tabular}{|c|c|c|c|}
\hline Independent Variables & Coefficient & $\begin{array}{c}\text { Standard } \\
\text { Error }\end{array}$ & $\begin{array}{c}\text { Significance } \\
\text { Level }\end{array}$ \\
\hline Intercept & 0.156 & 0.468 & 0.741 \\
\hline National bank growth & 0.682 & 0.147 & 0.000 \\
\hline Reserve center times national bank growth ${ }^{\mathrm{b}}$ & -0.115 & 0.063 & 0.080 \\
\hline Growth in land values, $1914-1920$ & 0.526 & 0.334 & 0.127 \\
\hline Ratio of farm to non-farm population & -0.328 & 0.655 & 0.621 \\
\hline Presence of voluntary insurance & 0.327 & 0.251 & 0.205 \\
\hline Presence of compulsory insurance & 0.609 & 0.189 & 0.004 \\
\hline
\end{tabular}

$R^{2}=0.683$

$\bar{R}^{2}=0.607$

b. Dependent variable: Growth in total assets of state-chartered banks, 1914-1920

\begin{tabular}{lccc}
\multicolumn{1}{c}{ Independent Variables } & Coefficient & $\begin{array}{c}\text { Standard } \\
\text { Error }\end{array}$ & $\begin{array}{c}\text { Significance } \\
\text { Level }\end{array}$ \\
\hline Intercept & 0.101 & 0.465 & 0.829 \\
National bank growth & 0.681 & 0.147 & 0.000 \\
Reserve center times national bank growth ${ }^{\text {b }}$ & -0.132 & 0.060 & 0.038 \\
Growth in land values, 1914-1920 & 0.555 & 0.333 & 0.107 \\
Ratio of farm to non-farm population & -0.283 & 0.654 & 0.669 \\
Presence of voluntary or compulsory insurance & 0.518 & 0.165 & 0.004
\end{tabular}

$R^{2}=0.670$

$\bar{R}^{2}=0.607$

${ }^{a}$ Asset growth is defined as the log difference of total assets. All variables are defined at the state level for a sample of 32 agricultural states.

${ }^{b}$ National bank growth in each state is used as a control for state-chartered bank growth. In reserve-center states, national bank growth may be larger, as it reflects growth of correspondent banks outside of the state as well. To control for this difference, I interact national banking growth with an indicator variable for states with reserve centers.

Source: Charles W. Calomiris, "Do Vulnerable Economies Need Deposit Insurance?" in Philip Brock, ed., If Texas Were Chile: Financial Risk and Regulation in Commodity-Exporting Economies (Washington, DC, 1990).

\section{CONTRASTING THE PERFORMANCE OF INSURED AND BRANCH BANKING}

The failings of deposit insurance systems stand in sharp contrast to their perceived political alternative, branch banking. States that allowed branch banking saw much lower failure rates-reflecting the unusually high survivability of branching banks-and responded well to the agricultural crisis by consolidating banks and expanding branching systems, where this was allowed.

From 1921 to 1929 only 37 branching banks failed in the United States, almost all of which operated only one or two branches. Branching failures were only 4 percent of branch-banking facilities, almost an order of magnitude less than the failure rate of unit banks for this period. In states hard hit by the agricultural crisis, branch banks' failure rates were roughly a fourth those of unit banks. In Arizona, Mississippi, and South Carolina-three hard-hit states with existing statewide branching 


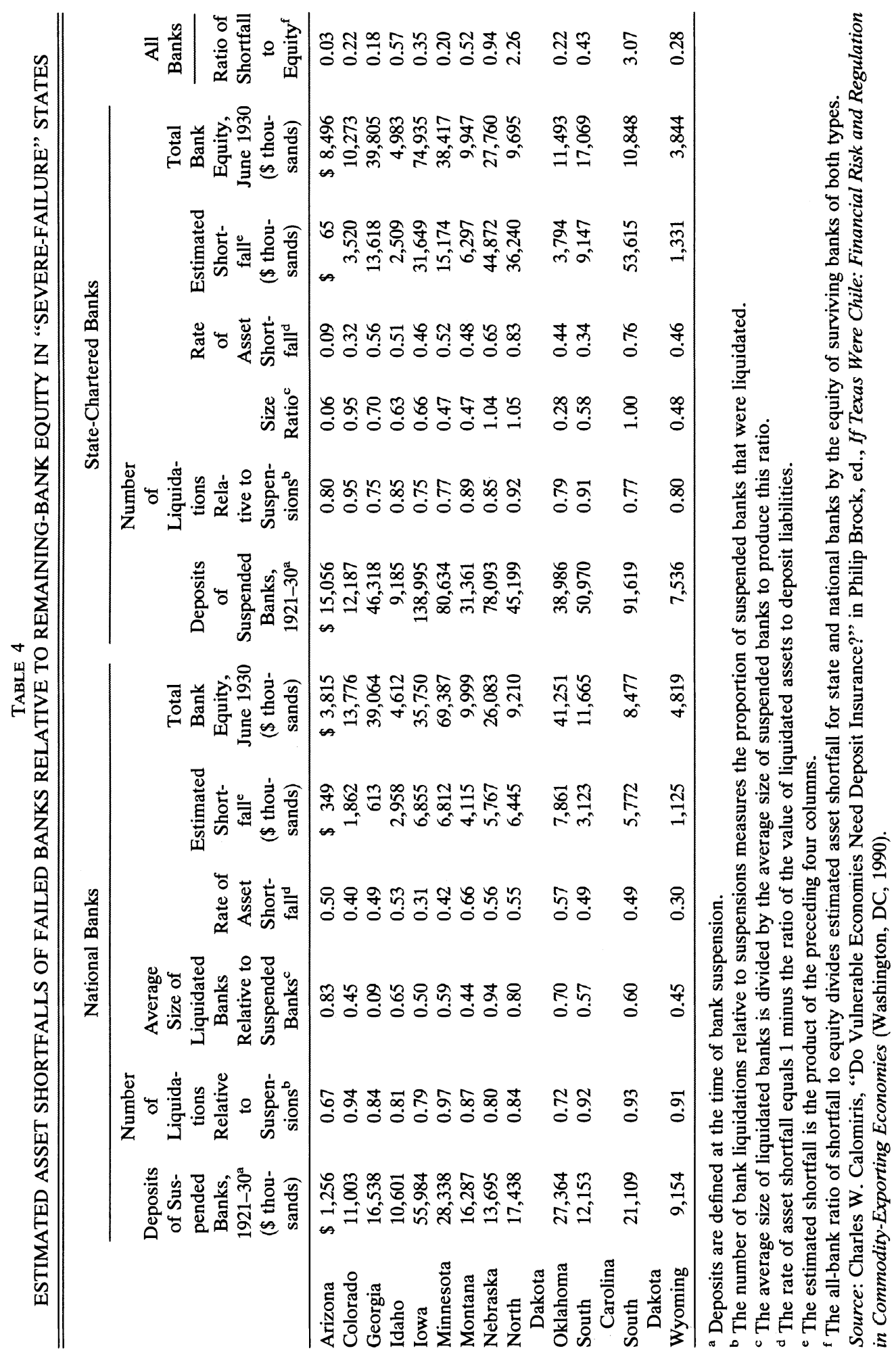


networks-existing branches survived especially well, and new entry into banking (allowed only in Arizona and South Carolina) was especially strong. ${ }^{13}$

Table 5 reports regression results on bank growth from 1920 to 1926 and 1920 to 1930. States that permitted expansion of branching saw substantially higher (and statistically significant) asset growth relative to other states, controlling for other influences. A comparison across the two time periods shows that the influence of branching persisted and grew stronger with the passage of time. The effect of the presence of deposit insurance was negative, but this mainly reflected a temporary retreat from the state systems until after the insurance laws were repealed. By 1930 previously insured state systems had recovered to roughly the same levels of assets as other unit-banking state systems.

Contemporaries often remarked on the unusual survivability and growth of branch banks in the face of the crisis. Many states altered their branch banking laws in response to these observations. From 1924 to 1939 the number of full or limited branch-banking states rose from 18 to 36 . Four of the 8 states that previously had opted for deposit insurance were among those liberalizing their branching restrictions during this period.

\section{CONCLUSION}

I conclude that unlimited branch banking, combined with the sort of privately administered insurance programs of antebellum Indiana, Ohio, and Iowa, would have been adequate to protect the payments system from exogenous disturbances that could produce banking panics. ${ }^{14}$ The greatest threats to systemic stability historically were unit banking and ill-conceived attempts to promote stability through government-controlled insurance, which actually produced quite the opposite effect by promoting excessive risk-taking.

The problems of moral hazard and adverse selection which arise in government deposit insurance systems are likely to be even more pronounced in today's federal insurance programs. The state insurance systems of the 1920 s limited interest paid on deposits, typically required ratios of capital to deposits in excess of 10 percent, and were funded by the accumulated contributions of members. Today's federal insurance plans do not restrict interest payments to depositors, require a trivial proportion of capital to deposits, and are supported by the full faith and credit of the federal government. Thus today's financial intermediaries can maintain higher leverage and attract depositors more easily by offering higher rates of return with virtually no risk of default. From this

\footnotetext{
${ }^{13}$ Again, for more detailed evidence, see ibid.

${ }^{14}$ The collapse of the 1930s demonstrates, of course, that if government policy makers want to destroy a banking system (in that case through deflation and monetary contraction) they have the power to do so.
} 
TABLE 5

REGRESSION RESULTS: LATE ASSET GROWTH AND BANK SIZE OF STATE-CHARTERED BANK ${ }^{\mathrm{a}}$

a. Dependent Variable: Growth in total assets of state-chartered banks, 1920-1926

\begin{tabular}{|c|c|c|c|}
\hline Independent Variable & Coefficient & $\begin{array}{l}\text { Standard } \\
\text { Error }\end{array}$ & $\begin{array}{l}\text { Significance } \\
\text { Level }\end{array}$ \\
\hline Intercept & 0.544 & 0.450 & 0.239 \\
\hline National bank growth & 0.602 & 0.235 & 0.018 \\
\hline Reserve center times national bank growth & 0.178 & 0.098 & 0.084 \\
\hline Ratio of farm to non-farm population & -0.404 & 0.346 & 0.254 \\
\hline Growth in land values, $1920-1925$ & 0.037 & 0.541 & 0.946 \\
\hline $\begin{array}{l}\text { Business failure rate, } 1921-1925 / \\
\text { Business failure rate, } 1917-1920\end{array}$ & -0.040 & 0.038 & 0.308 \\
\hline $\begin{array}{l}\text { Presence of deposit insurance (excluding } \\
\text { Nebraska) }\end{array}$ & -0.190 & 0.126 & 0.146 \\
\hline Out-of-city branch banking ${ }^{d}$ & 0.179 & 0.124 & 0.163 \\
\hline Within-city branch banking ${ }^{\mathrm{d}}$ & 0.204 & 0.132 & 0.136 \\
\hline
\end{tabular}

$R^{2}=0.601$

$R^{2}=0.462$

b. Dependent Variable: Growth in total assets of state-chartered banks, 1920-1930

\begin{tabular}{|c|c|c|c|}
\hline Independent Variable & Coefficient & $\begin{array}{l}\text { Standard } \\
\text { Error }\end{array}$ & $\begin{array}{c}\text { Significance } \\
\text { Level }\end{array}$ \\
\hline Intercept & 1.539 & 0.449 & 0.002 \\
\hline National bank growth & 0.124 & 0.200 & 0.539 \\
\hline Reserve center times national bank growth ${ }^{\mathrm{b}}$ & 0.078 & 0.115 & 0.502 \\
\hline Ratio of farm to non-farm population & -0.936 & 0.405 & 0.030 \\
\hline Growth in land values, $1920-1930$ & -0.386 & 0.551 & 0.490 \\
\hline $\begin{array}{l}\text { Business failure rate, 1921-1929/ } \\
\text { Business failure rate, 1917-1920 }\end{array}$ & -0.072 & 0.044 & 0.118 \\
\hline $\begin{array}{l}\text { Presence of deposit insurance (excluding } \\
\text { Nebraska) }\end{array}$ & -0.065 & 0.140 & 0.647 \\
\hline Out-of-city branch banking ${ }^{d}$ & 0.398 & 0.150 & 0.014 \\
\hline $\begin{array}{l}\text { Within-city branch banking } \\
R^{2}=0.625 \\
R^{2}=0.495\end{array}$ & 0.428 & 0.161 & 0.014 \\
\hline
\end{tabular}

a Asset growth is defined as the log difference of total assets. All variables are defined at the state level for a sample of 32 agricultural states.

b National bank growth in each state is used as a control for state-chartered bank growth. In reserve-center states, national bank growth may be larger, as it reflects growth of correspondent banks outside of the state, as well. To control for this difference, I interact national banking growth with an indicator variable for states with reserve centers.

c Nebraska's insured banks remained open long after they were known to be insolvent. Thus data for Nebraska on total assets of state-chartered banks overstate actual state-chartered bank assets for the 1920s. For this reason Nebraska was excluded from the group of insured states in these regressions.

d The indicator variable for out-of-city branching takes a value of 1 for states that allowed branching outside the home city of the bank, 0 otherwise. The within-city indicator takes a value of 1 for states that allowed branching only within a bank's home city, 0 otherwise.

Source: Charles W. Calomiris, "Do Vulnerable Economies Need Deposit Insurance?" in Philip Brock, ed., If Texas Were Chile: Financial Risk and Regulation in Commodity-Exporting Economies (Washington, DC, 1990). 
perspective the unprecedented losses of Texas banks and thrifts in the 1980s should come as no surprise.

Reformers of current deposit insurance plans might apply the lessons of the successful antebellum insurance programs by creating a greater role for incentive-compatible self-regulation and coinsurance among banks. Today's futures clearinghouses, which regulate members' risks and provide incentive-compatible liquidity coinsurance, also successfully apply this principle.

A role remains for the government, however, in regulating bank insurance programs. At the very least the government should ensure freedom of entry into coinsuring groups of banks and competition among groups (by creating, for example, separate groups that overlap geographically). In a unit-banking scenario, the need for many groups (to keep group size small enough to encourage monitoring) dictates special attention to potential problems of local market monopolization. In contrast, today's futures clearinghouses can rely on national, and soon international, competition to limit the power of any group.

One might also argue, notwithstanding the evidence from the $1920 \mathrm{~s}$ reported here, that government should provide some stop-gap protection against systemic collapse of the banking system-that is, shocks greater than those that could be absorbed by bank capital. To this end the government might establish an insurance plan with a "deductible." For example, coinsurance among banks would be relied on entirely for reimbursing depositors of the first banks that failed; the government would share increasingly in subsequent losses of failed banks. This would provide the incentives for interbank discipline and for market discipline of banking coalitions as a whole without risking systemic collapse. ${ }^{15}$ Moreover, since it is likely that the government will intervene in such crises even without an explicit commitment to do so, it would be best to have that commitment spelled out. This would limit Congressional intervention to serve constituents' interests.

Absent the political feasibility of fully self-regulating, coinsuring groups of banks, some smaller steps could be taken to reduce the costs of government deposit insurance by enlisting the assistance of banks in the supervision process. ${ }^{16}$ For example, banks could be assigned to groups, and banks within a group could be penalized (with higher insurance premia) for failing to detect and report violations or insolvency of other banks in the group. At the very least this would provide a strong counterbalance to political encouragement of excessive "forbearance" by creating an interest group that would have an incentive to monitor banks and "blow the whistle" early on insolvent institutions.

\footnotetext{
${ }^{15}$ I thank Henning Bohn for suggesting this to me.

${ }^{16}$ I thank Peter Diamond for suggesting the usefulness of state-contingent insurance premia in limited supervisory banking coalitions.
} 